Article

\title{
"That is Not What I Live For": How Lower-Level Green Employees Cope with Identity Tensions at Work
}

\author{
Susanne Blazejewski ${ }^{1, *}{ }^{\oplus}$, Franziska Dittmer ${ }^{1}$, Anke Buhl ${ }^{1}$, Andrea Simone Barth ${ }^{1}$ and \\ Carsten Herbes $^{2}$ (D) \\ 1 Chair for Sustainable Organization and Work Design, Alanus University of Arts and Social Sciences, \\ 53347 Alfter, Germany; franziska.dittmer@posteo.de (F.D.); anke.buhl@gmx.de (A.B.); \\ andrea-simone.barth@alanus.edu (A.S.B.) \\ 2 Institute for International Research on Sustainable Management and Renewable Energy, Nuertingen \\ Geislingen University, 72622 Nürtingen, Germany; carsten.herbes@hfwu.de \\ * Correspondence: susanne.blazejewski@alanus.edu
}

Received: 16 June 2020; Accepted: 12 July 2020; Published: 17 July 2020

\begin{abstract}
Research on green identity work has so far concentrated on sustainability managers and/or top-management actors. How lower-level green employees cope with identity tensions at work is, as yet, under-researched. The paper uses an identity work perspective and a qualitative empirical study to identify four strategies that lower-level employees use in negotiating and enacting their green identities at work. Contrary to expectations, lower-level green employees engage substantially in job crafting as a form of identity work despite their limited discretion. In addition, the study demonstrates that lower-level green employees make use of identity work strategies that uphold rather than diminish perceived misalignment between their green identities and their job context.
\end{abstract}

Keywords: identity work; job crafting; corporate sustainability; green employees; lower-level employees

\section{Introduction}

Employees at lower levels in the corporate hierarchy have been recognized for playing a potentially pivotal role for the sustainable development of organizations [1]. In particular, "green employees" [2] with a strong sustainability orientation are seen to be instrumental for pushing pro-environmental workplace behavior in organizations. Much of the literature so far, however, conceptualizes non-managerial employees as mere enactors of corporate sustainability agendas that are set by the upper echelon of the organization. Recently, several authors [2-7] have drawn attention to more proactive green behaviors of intrinsically motivated employees that go well beyond their formal job roles.

Green identities are increasingly being recognized as important drivers for high-intensity green behavior, such as initiative-taking, but are considered as yet under-researched [2,8], particularly with regard to green behavior at the workplace. Ciocirlan [2] theorizes that green employees who hold an "environmental identity" are characterized by an "intrinsic desire to protect the environment through work" [2] (p. 2). Research in the environmental psychology field provides some insights on the role of identity as an antecedent in spillover processes between green consumption at home and at work [9-12], but conceptualizes green identity largely as a fixed, essentialist construct. In turn, authors in organization studies focus on the processes involved in constructing and maintaining one's green identity with regard to competing or contradictory demands and discourses prevalent in the actor's workplace context. Based on the concept of identity work, these authors are able to identify varying green identity positions [13-16] employed by individual actors in negotiating their green 
identities at work. Identity work strategies help actors cope with tensions between their self-identity as "green" and their workplace context. Whereas identity work strategies concern the narrative self-concept of green employees, job crafting relates to how actors see and thus constitute their job tasks. Identity-related job crafting may thus enable actors to better align their jobs and organizational roles with their self-identities $[17,18]$. Identity misalignment, incoherence, or asymmetry are considered to impede individual well-being and the experience of positive meaning at work [17-22].

Research on green identity work is so far, however, largely limited to the investigation of top management and sustainability managers [13-16]. Carollo and Guerci [16] maintain, for instance, that sustainability managers are "a key group" because of their organizational centrality. In their view, sustainability managers experience high identity pressure due to their paradoxical role as members of the managerial elite and as official guardians of sustainability [16]. In our view, employees outside the sustainability department and on lower levels of the organization might also perceive strong misalignment between their green identities and their job roles or organizational contexts. Lower-level employees are expected to have less discretion due to their limited formal autonomy and high job interdependencies [17], which might inhibit them from enacting their green identities at work in a satisfying way. In addition, while other organizational actors will perceive green behavior by sustainability professionals as in-role and, therefore, in line with social expectations, lower-level employees in other job roles might have trouble gaining acceptance for their green identities and behaviors from colleagues and supervisors. We can therefore expect that green identity work strategies by lower-level employees differ from those employed by sustainability managers.

Extending the identity work perspective on green identity misalignment to lower hierarchical levels, this paper therefore addresses the following question: How do lower-level green employees cope with identity misalignment at work? We aim to contribute to the literature on green identity in three ways: First, we provide a typology of green identity work strategies of lower-level employees, a group of organizational actors as yet under-researched. Second, we demonstrate that the identity work strategies in use by lower-level green employees stabilize an identity construction that limits rather than unfolds their potential for green transformation on the organizational level. Third, we identify resources that support the identity work strategies in use by lower-level employees and that may function as boundary conditions by preventing a more productive and satisfying identity alignment at work.

The paper is structured as follows: First, we introduce our theoretical perspective and situate our research in the identity work literature. In particular, we conceptualize job crafting as one form of identity work. We then present the methodological approach and the findings of a qualitative study on green lower-level employees in Germany. Third, we identify and discuss four identity work strategies on the basis of our empirical data and their linkage to the lower-level hierarchical positions of our respondents in view of the literature on identity work in the final section.

\section{Theoretical Background}

In order to better understand how green lower-level employees handle identity tensions at work, we draw on two theoretical perspectives, identity work and job crafting. Identity work is a mature framework that allows the delineation and explanation of how actors negotiate their various and sometimes tensional or competing identities in relation to available discourses and identity anchors in specific contexts, such as their workplaces. In turn, the job crafting perspective helps us to account for actors' attempts to reconfigure their jobs in response to a misalignment between preferred identities and the actors' formal job design. This dual theoretical framing allows us to analyze how green lower-level actors engage in identity work and job crafting techniques in coping with identity struggles at work and how both strategies are interrelated. Integrating both approaches also helps to overcome the current division in the research literature where, according to Kira and Balkin [17], authors tend to stick to either one of the two perspectives. While literature on the identity struggle in organizations has largely concentrated on identity work and the construction of narrative identities that attenuate or 
integrate tensions, according to Kira and Balkin [17] (p. 132, our emphasis), "the idea of employees developing their work to align it better with their identities has remained at the margins of studies."

\subsection{Green Identity Work}

Following Sveningsson and Alvesson [23] (p. 1165), we maintain that "identity work refers to people being engaged in forming, repairing, maintaining, strengthening, or revising" their identity constructions, i.e., their "subjectively construed understandings of who they were, are, and desire to become" [24] (p. 20). Identities are seen as emerging through discourses [23] to which individuals refer in their meaning-making processes [25]. Identity work thus enfolds largely in the realm of self-narration [23,25-29], although authors generally acknowledge "that identity construction also occurs through its ongoing accomplishment in situated practices" [30] (p. 506), that is, through identity enactment [31-34].

The notion of struggle or tension is inherent to the concept of identity work: On the one hand, in view of the fragmented discourses in society $[35,36]$, individuals hold multiple, eventually competing identities [37], with identity struggle being particularly prevalent in managerial roles [26,38,39]. On the other hand, individuals are constantly seeking to attain a sense of coherence across identities through identity work [23]. Recent studies on the identity work of sustainability managers as well as ecopreneurs $[13,15,16,40]$ show how actors cope with tensions around their identities at work and how they construct self-narratives that provide a sense of coherence despite (or on the basis of) these perceived tensions. Although all of these studies focus on the identity work of managers instead of the lower-level employees, it is still instructive to briefly review the green identity work strategies identified for the managerial level. They later serve as a point of reference when we discuss the specific strategies employed by green lower-level employees below. Table 1 provides an overview of perspectives on green identity work in recent research.

Based on their sample of sustainability managers, Wright, Nyberg, and Grant [13] identify three identity positions that actors construct in responding to identity tensions at their respective workplaces (Table 1). Each identity construction allows actors to subjectively make sense of their self-concept as "green" in a context dominated by business logics and organizational constraints. "Rational managers" seek to frame their green initiatives as business opportunities so as to reconcile them with the dominant business logic in place in their organizations. "Green change agents" portray themselves as focusing on organizational development and learning as a path towards more sustainability. In turn, "committed activists" see their green projects in their organizations as a contribution to the greater societal movement against climate change.

While Wright, Nyberg, and Grant [13] focus on these three identity positions taken by sustainability managers, the study conducted by Carollo and Guerci [16] reveals the role of metaphors in identity work. Perceiving the tension between job requirements, organizational constraints, and business logics, on the one hand, and their sustainability norms, values, and identities, on the other hand, as an ongoing, basically un-resolvable struggle, actors in this sample develop metaphors or images (e.g., "virus", "activist in a suit", "undercover consultant") that help them to make sense of the paradoxes inherent in their jobs roles.

The work by Allen, Marshall, and Easterby-Smith [15] reveals a different pattern of handling identity tensions related to sustainability in the work context. Their sample of senior managers in the energy and power industry does not seek to address or integrate the struggles or paradoxes into their identity work. Instead, they use nine discursive processes of "distancing and deflection" [15] (p. 8) in order to keep sustainability tensions away from themselves and their companies. They either relegate the need for action onto others (e.g., China, politicians, scientists), maintain that dominant economic norms preventing sustainability are beyond their reach, or legitimate inaction through a Hobbesian perspective on human beings as being inherently selfish [15]. Similarly, Alvesson and Robertson [41] demonstrate for their sample of top managers in the financial sector how a stance of rationalism and professionalism enables them to keep identity tensions at bay [41]. 
Table 1. Perspectives on green identity work $[15,40]$.

\begin{tabular}{ccc}
\hline Actors in Focus & Identity Work Strategies/Positions & Source \\
\hline \multirow{2}{*}{$\begin{array}{c}\text { Sustainability } \\
\text { managers }\end{array}$} & $\begin{array}{c}\text { Self-narratives and discourses resisting and/or } \\
\text { enabling green identities, e.g., green change } \\
\text { agent, rational manager, committed activist }\end{array}$ & $\begin{array}{c}\text { Wright, Nyberg, and Grant [13]; } \\
\text { Cherrier, Russel, and Fielding [40] }\end{array}$ \\
\cline { 2 - 3 } Top managers & $\begin{array}{c}\text { Metaphors help to make sense of green } \\
\text { identity tensions } \\
\text { Deflect and distance green identity tensions } \\
\text { through rationalization and legitimization }\end{array}$ & $\begin{array}{c}\text { Carollo and Guerci [16] } \\
\text { and Easterby-Smith [15]; Alvesson } \\
\text { and Robertson [41] }\end{array}$ \\
\hline
\end{tabular}

In spite of identifying highly interesting and also diverging strategies through which actors seek to cope with identity struggles arising around sustainability issues at work, empirical research is, as yet, largely limited to the managerial stratum in organizations. While the studies by Allen, Marshall, and Easterby-Smith [15], Cherrier, Russell, and Fielding [14], and Alvesson and Robertson [41] look at senior management in the healthcare, power, and financial industries, respectively, Wright, Nyberg, and Grant [13], as well as Carollo and Guerci [16], focus on sustainability managers across industries. It remains as yet unclear, whether lower-level employees are also able to distance themselves from competing or contradictory claims on their green identity or whether and how they handle identity struggles through metaphorical self-conceptions that help to make sense of an inherently paradoxical situation. Whereas sustainability managers can be expected to possess some discretion for integrating and/or exhibiting their green self-concepts at work (e.g., in their formal job tasks, in their team), lower-level employees are neither in formal positions to substantially shape their organizations' or their coworkers' green beliefs and practices, nor can they expect to adjust their own job in such a way as to fit their green identities.

\subsection{Job Crafting as Identity Work}

A further important perspective on identity struggles is provided by the job crafting literature. While research on green identity struggles so far mainly focuses on actors' discursive strategies to cope with conflicting identities and identity struggle, the job crafting approach more closely looks at the tensions arising between identities and the roles or tasks actors fulfill at work. With this paper, we seek to establish identity-related job crafting as an additional form of identity work for green actors in organizations. Job crafting is defined as "the process of employees proactively changing the boundaries that comprise their jobs" [18] (p. 283), thereby modifying "the meaning of the work ( . . ) in ways that allow employees to reframe the purpose of the job and experience the work differently" [42] (p. 186). Boundaries are "mental fences" [18] (p. 283) that help people to physically, emotionally, relationally, and cognitively delineate what they consider their jobs to be.

According to Wrzesniewski and colleagues [18] (p. 285), identity is related to job crafting "in important ways" in that identity is both a driver of job crafting and an outcome. As a driver of job crafting, identity might lead to an actor re-configuring his or her tasks at work in line with that identity. Employees are likely to prioritize tasks that align with their preferred identities to cognitively emphasize aspects of their work that fit their identities and to seek collaborations with colleagues who support their identities [42]. At the same time, identities may eventually change when job crafting involves the adoption of new tasks and relationships at work, i.e., through learning [43]. Job crafting might open up new possibilities to anchor and enact identities at work and thus to experience positive meaning in the workplace [17].

Kira and Balkin [17] maintain that individuals may basically pursue two different paths in responding to a misalignment between their identities and their jobs: They can transform their selves, that is, engage in identity work and sensemaking, and they can try to change the job, that is, engage in job crafting (Figure 1). The authors further propose that individuals are likely to first try to cope with 
misalignment through crafting their jobs before adjusting their identities, since identity work comes at a higher personal cost [17]. However, for employees on the lower level of the organization, a lack of job discretion and higher job interdependencies might put limits on job crafting, forcing actors to endure misalignment and/or re-configure their identities [17]. Both propositions are highly relevant for the context of green lower-level employees in our study, but empirical evidence is missing so far. We use the theoretical discussion provided by Kira and Balkin [17] to inform our empirical exploration of identity work and job crafting, as well as the discussion of our findings regarding lower-level employees' preferred alignment strategies.

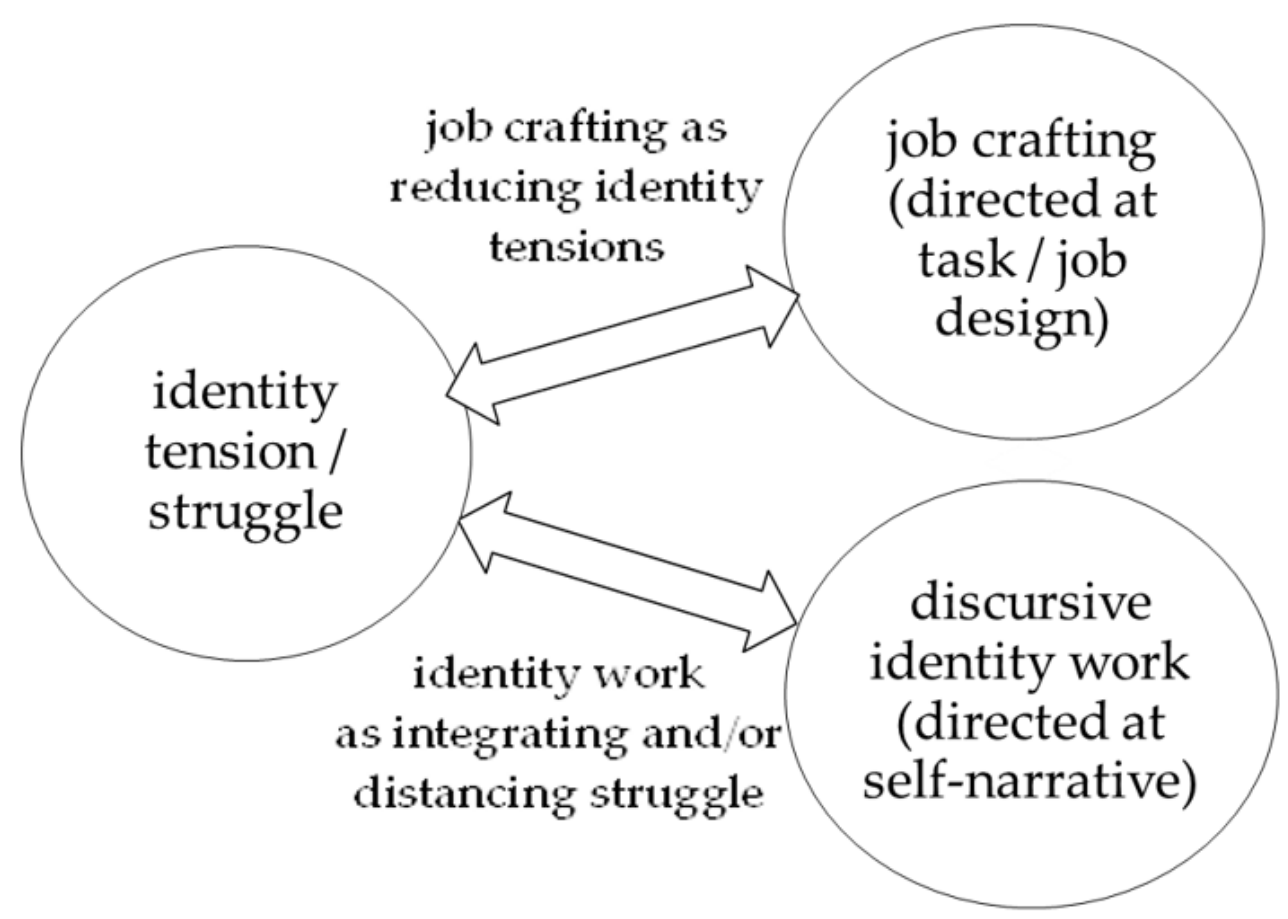

Figure 1. Paths of identity work (based on Kira and Balkin [17]).

The literature on job crafting provides different typologies of job crafting techniques and strategies [42,44]. A study by Berg and colleagues on "unanswered callings" [43] seems particularly instructive in our context, since the authors suggest that lower-level employees craft their jobs differently when compared to higher-level staff. In particular, Berg and colleagues demonstrate based on their qualitative data that employees with more discretion, e.g., university lecturers, tend to engage in more job crafting techniques than those with less autonomy [43]. According to their findings, individuals in the lower levels of organizations instead resort to "leisure crafting techniques" when job crafting is difficult or ineffective [43]. Berg and colleagues identify two leisure crafting techniques: "Vicarious experiencing" when actors seek fulfillment of their unanswered callings through others, e.g., a teacher who could have been a violinist has her children pursue a career in music, and "hobby participating" when actors follow their calling in volunteer activities outside the work context [43]. Since the authors concentrate on the concepts of crafting and callings, it remains unclear whether and how these different crafting techniques are associated with identity work processes. The quotes provided [43], however, do hint at a strong linkage between job crafting techniques and identity work, as already suggested in the theoretical discussion by Wrzesniewski, LoBuglio, Dutton, and Berg [18].

\subsection{Resources Facilitating Identity Work and Job Crafting}

For both streams of research—identity work and job crafting-the resources facilitating a certain form of identity work or job crafting strategy are a matter of interest. The job crafting literature emphasizes the role of job crafting in seeking and developing personal and structural (job) resources that 
help cope with job demands [45]. Through job crafting, actors might, for instance, be able to strengthen positive feedback or support systems [45]. In the identity work literature, scholars emphasize that resources can enable or delimit identity work. Dutton et al. [46] highlight social resources, such as personal ties to like-minded individuals, as enabling identity work and as strengthening employees who endure stress and struggles related to identity work. Kornberger and Brown [47] show how notions of "ethics" are used in identity work as discursive resources that enable individuals and groups to legitimate particular working modes. Here, actors can draw on established and legitimated discourses on ethics to maintain and bolster their identity positions. Similarly, Sveningsson and Alvesson [23] demonstrate how a manager draws from various discourses in their identity construction in order to handle contradictory job demands. In their study on investment bankers, Alvesson and Robertson [41] show how these actors rely on institutionalized codes of dress and behavior at work in order to enable "identity minimalism", i.e., a strategy of distancing rather than integrating conflicting identity positions [41]. For the case of lower-level green employees, it is as yet unclear which resources and constraints enable or foreclose specific identity work strategies.

\section{Studying Green Employees' Identity Work: Methodology}

The present study is based on in-depth narrative interviews with 19 lower-level green employees from diverse working contexts in Germany. Table A1 presents an overview of the interviewees and their employment positions. Since some of the interviewees changed their status over the course of data collection, we also report on the actual work situation at the end of 2016 (in brackets). Interviewees were identified via a snowballing technique and thus represent a purposive sample, as recommended by Ciocirlan in view of the early stage of research on green employees [2]. Girschik et al. [5] rightly draw attention to the fact that the identification of internal Corporate Social Responsibility (CSR) activists, similarly to strongly engaged green lower-level employees, is difficult for two reasons: (i) Since they are not part of the management cadre, their visibility in organizations might be low, and (ii) we cannot deduce their status as green activists on the basis of their action, since green change and high-intensity environmental workplace behavior are also conducted by actors who do not hold a green identity, but are forced, legitimated, or incentivized to do so. We therefore focus on self-concepts and peer-to-peer nominations). We commenced our empirical work by interviewing people who had recently won a local "climate saver" award (awarded once a year by local authorities for exemplary citizen engagement for renewable energies or energy-saving projects) and then asking them for further green contacts among their acquaintances. From the resulting sample, we selected only those for this paper where the respondents reported being non-managerial employees in companies. Self-employed or public sector employees were excluded from further analysis. Self-employed green employees are expected to enjoy much more discretion over their own tasks and interactions on the job than dependent employees. In turn, public employees benefit from a considerably lower job risk in Germany and less performance pressure when compared to employees in the corporate sector, and thus might be able to more freely engage in green initiatives alongside their formal job. All remaining 19 respondents considered for this study (i) work as employees in non-managerial positions in companies, (ii) are not formally assigned sustainability tasks or responsibilities, e.g., as part of the sustainability department, (iii) do self-identify as sustainability-oriented or "green", and do strongly engage in green activism in their private spheres. Our conceptualization resonates with the construct of environmental identity as discussed by Blatt $[48,49]$, who emphasizes the linkage between a pro-environmental self-identity and a self-concept in which the actor conceives him-/herself as acting in a pro-environmental way.

Interviews, which lasted between 45 and $120 \mathrm{~min}$, were recorded and transcribed. All interviews were conducted outside the individuals' workplaces (e.g., in a café or on the university premises) in order to encourage unrestricted speech. During the interviews, interviewees were encouraged to talk about their past, present, and future pro-environmental behavior and green initiatives in their private and public lives and at their respective workplaces (Table A1). We abstained from openly using an identity frame during the interview, i.e., we did not ask direct questions on respondents' self-concepts, 
but rather focused on their activities, projects, and experiences as green employees in their respective work contexts (see also [16,50]). Only afterwards did it become apparent to us that interviewees, when talking about their pro-environmental initiatives, were frequently referring to self-conceptualizations and explicitly linked their activities to narratives about who they were or wanted to be at or outside the workplace. Although interviews have been questioned as an adequate data source for identity work [51], we contend with Allen et al. [15] and Lucius-Hoene and Deppermann [52] that actors do much of the identity work by themselves and through self-accounts of their doings, and need to be taken seriously as a source of information [53]. Like identity work, job crafting occurs in subjective constructions, perceptions, and narrative reflection of actors' changes to their job tasks, relationships, and cognitions, and thus studies also tend to rely on narrative interviews or other self-reported, perceptual data $[43,54,55]$. It is not imperative to an actor's job crafting whether others notice or acknowledge their crafting efforts, although positive feedback will help to sustain them, and formal recognition might be a result of continuous and successful crafting [42].

We interpreted our data through an inductive lens and in the grounded-theory tradition $[53,56]$. Although previous work has identified green identity work strategies of managers [14-16], we felt that the specific situation of lower-level employees warranted an entirely open approach. In addition, we suspected that the strategies provided by previous research would be too broad to accommodate different approaches taken by actors, who all described themselves as "committed activists" [13] alike. Accordingly, we let our first-order categories (see Table 2) emerge from the data itself. We then looked for similarities and differences arising from the first-order coding, which led us to a pattern of four identity work strategies and three kinds of resources supporting these identity work strategies. Following the actors' own phrasing, we do not separate between identity work and job crafting techniques in our data structure (cf. [17]). The ways interviewees refer to their self-construction and talk about making changes to their jobs are hardly separable in the interviewees' narratives. Please note also that each actor made use of various identity work strategies, so we cannot assign actors to a single specific form of strategizing his or her identity.

\section{Findings: Green Identities at Work}

\subsection{Perceived Misalignment: "That Is Not What I Live For"}

Before we present the identity work strategies in detail, it seems necessary to report our findings regarding the perceived misalignment and struggle of green lower-level employees at work. All interviewees in our sample explicitly described tensions emerging between their work context and their green identities. They characterize their work context as largely unsupportive regarding pro-environmental behavior, and also clearly see that their current position does not allow them to effectively change the exclusionary context in their organization. Interviewees also reveal that they often feel unable to pursue green projects as intended because their workload does not allow them to carry out activities in addition to their formal role.

"When I am engaged [for my green projects] now, and spend time to get access to different fields, that wouldn't get me anywhere, except that I get a roasting, because I don't fulfill my working objectives." (Sara)

The tensions between the organizational environment and personal beliefs are not varnished or warded off, but explicitly connected to one's self and identity. Interviewees' language also gets quite emotional when describing their tense relationship with their work environment:

"Our main customers are food processing companies, mainly meat and fish processing. (... ) And that naturally does not go well with my way of thinking. And part of that is disgusting. And so I ask myself sometimes if I am in the right place. (... ) Because that goes against the grain. Because that is not what I live for." (Susan) 
Their conscious reflection on the missing alignment between their own green attitudes and their organizations' policies forces the interviewees to continually seek a personal answer to the question why and how they can maintain and enact their green identities within or despite the misaligned workplace context.

\subsection{Identity Work Strategies}

The explorative data analysis reveals four ways of handling the perceived misalignment between the interviewees' green identity and the respective work context. We briefly describe the four identity work strategies (Table 2) surfacing from our data and then take a closer look at constraints and resources enabling these forms of identity work.

Table 2. Identity work strategies.

\begin{tabular}{|c|c|c|}
\hline $\begin{array}{l}\text { Identity Work } \\
\text { Strategy }\end{array}$ & $\begin{array}{l}\text { First Order } \\
\text { Categories }\end{array}$ & Exemplary Quote \\
\hline \multirow[t]{2}{*}{ Exposing } & $\begin{array}{l}\text { display green } \\
\text { attitudes }\end{array}$ & $\begin{array}{l}\text { "Back when I started to work for [my company], I did support for a lot of nuclear } \\
\text { power plants, had no problem with that at all. And that became a problem for } \\
\text { me. (...) Meanwhile I have no inhibitions at all anymore from carrying a } \\
\text { "Nuclear Power-no thanks!" sticker on my bike. ( ... ). Well, but we do support } \\
\text { for nuclear power plants and that gradually did become more and more of a } \\
\text { problem for me." (Richard) }\end{array}$ \\
\hline & actively resist & $\begin{array}{l}\text { "At that time, I asked [my supervisor], Mr. [ ... ], what should I do with the } \\
\text { sulfuric acid? [He said]: 'Put it in the refuse container outside'. And I said: 'No, } \\
\text { I won't do that, even if you would dismiss me [ ... ]. At that time I started to } \\
\text { make war with him." (Elisabeth) }\end{array}$ \\
\hline \multirow{3}{*}{ Enduring } & $\begin{array}{l}\text { accept } \\
\text { non-resolution }\end{array}$ & $\begin{array}{l}\text { "And I think other colleagues are shaking their heads and think: What is going } \\
\text { on with her? }(\ldots) \text {. With one colleague I had a heated discussion about coffee } \\
\text { capsules. They are a red rag to me }(\ldots) \text {. I find it absolutely }(\ldots) \text { an incredible } \\
\text { environmental sin }(\ldots) \text { : Well that [discussion] stayed unsolved: He continues to } \\
\text { buy coffee capsules and I continue to buy my fair-trade coffee." (Sara) }\end{array}$ \\
\hline & postpone & $\begin{array}{l}\text { “And you have to have such a, how would you say, resilience. So again and } \\
\text { again, okay, that doesn't work/can't be done/is impossible, a pity, let's do } \\
\text { something new. That doesn't work either. (... ) No? And then it goes on and on } \\
\text { like this and after the hundredth time." (Megan) }\end{array}$ \\
\hline & Do not let up & $\begin{array}{l}\text { "I will try this again and again. Because it is my personal conviction. And as } \\
\text { long as I can influence this, I will also do that." (Sara) }\end{array}$ \\
\hline \multirow[b]{2}{*}{ Dodging } & $\begin{array}{l}\text { hidden green } \\
\text { action }\end{array}$ & $\begin{array}{c}\text { "So I went a little beyond my competences now. [ . . ] But by complying with the } \\
\text { [company] rules, it doesn't work, if you stick to all formalities, nothing ever gets } \\
\text { done. [ ... ] If you really comply with all of how it is written, that's actually } \\
\text { worth nothing." (Scott) }\end{array}$ \\
\hline & building niches & $\begin{array}{l}\text { "I have told some colleagues about the things I am doing in this [project] in } \\
\text { [foreign country]. Some colleagues are now regularly donating money for the } \\
\text { project. I have set up a standing order for them. [ ... ] I also have a few fair-trade } \\
\text { chocolate bars at my workplace that everyone can buy. And the money that } \\
\text { remains goes to the project in [foreign country]. From time to time, I also talk } \\
\text { about how coffee or chocolate is produced." (Richard) }\end{array}$ \\
\hline \multirow{3}{*}{ Dissolving } & $\begin{array}{l}\text { changing roles } \\
\text { or employers }\end{array}$ & $\begin{array}{c}\text { "And then that was a new energy supplier on a greenfield site. And then, there, } \\
\text { I had the freedom to do everything in a way like I've had in my mind for a long } \\
\text { time. That you'd do it the right way. There was no moron who would dictate } \\
\text { something to me." (Patrick) }\end{array}$ \\
\hline & $\begin{array}{l}\text { Starting up } \\
\text { green }\end{array}$ & $\begin{array}{l}\text { "That was in 20XX, when I stopped working for [Company X], went into early } \\
\text { retirement, and, after that, since then, I am on the road as an independent } \\
\text { consultant and try to counsel solar-energy or wind-energy companies. (... ) and } \\
\text { I made a profession out of my calling, yes." (William) }\end{array}$ \\
\hline & $\begin{array}{c}\text { shift } \\
\text { engagement }\end{array}$ & $\begin{array}{c}\text { "I've reduced my working hours a bit, because I think, that is my strategy [ ... ]. } \\
\text { Well, so I've made my peace with it and work is for [ ... ], yes, to earn money. } \\
\text { But, yes, I believe I've shifted a lot of my engagement towards my private life. } \\
\text { Yes, it's like two worlds, right? The one is for business, and how I live my private } \\
\text { life is just very different." (Rachel) }\end{array}$ \\
\hline
\end{tabular}




\subsubsection{Exposing}

Interviewees using the "exposing" strategy of identity work openly display their green identity. They refrain from hiding or downplaying their green identity despite being in a context where they must expect being ridiculed or opposed by supervisors or fellow workers. Thomas composed and performed a song in his company's entrance hall in order to draw attention to water and energy waste at the workplace. Richard deliberately put a "Nuclear power-no, thanks" sticker on his bike, which he uses to pedal the extensive premises of his company. He works at a company that actually produces supplies for nuclear power plants. He thus hopes to make a visible, personal statement in order to provoke reactions from his colleagues. When asked to lead a team working on a nuclear power plant project, he also made his opposition clear by rejecting the offer. Richard reported that his open stance not only helped to him stay true to himself, but was also largely accepted by colleagues and supervisors.

According to our data, exhibiting takes two forms: Visually displaying a green identity and actively resisting non-green behavior (Table 2).

\subsubsection{Enduring}

We found that the "enduring" strategy appears to be the dominant form of handling identity tensions at work in our sample. Interviewees feel that they are neither in the position to change their organizations' sustainability practices (mainly due to their subordinate roles), nor do they feel ready to leave the exclusionary context. Although one interviewee (Megan) explicitly referred to the phrase of "leave it, love it, or change it", interviewees often reported not taking any of the three alternative routes. Instead, they seek ways to stay in the non-green environment, which they still find hard to tolerate. "Enduring" denotes identity work which, on the one hand, protects the individual's self-concept as a green employee, since actors do not need to engage in a potentially painful re-negotiation of their identity. On the other hand, they also do not feel pressured to engage in equally exhausting struggles with their exclusionary environment in an endeavor to change the people, structures, and norms in their working context. By "enduring", employees postpone individual and organizational changes, prolong potential pay-offs from their green initiatives into the future, or simply hope that their persistence in raising green issues may eventually yield fruit in the future. Apart from simply staying on, "enduring" involves three sub-processes (see Table 1): Accepting non-resolution, postponing pay-offs into the future, and persisting. Sara describes how she succeeds in tolerating the non-green attitude and behavior of a coworker while, at the same time, keeping up her efforts to convince them of her own more sustainable approach:

"And I think other colleagues are shaking their heads and think: What is going on with her? [ ... ]. With one colleague I had a heated discussion about coffee capsules. They are a red rag to me [ ... ]. I find it absolutely an incredible environmental sin [ ... ]. Well, that [discussion] stayed unsolved: He continues to buy coffee capsules and I continue to buy my fair-trade coffee." (Sara)

The postponing sub-process enables actors to legitimize their staying in the exclusionary work context by deferring action and/or the effects of their green engagement into an as yet unknown future. For this strategy, respondents frequently make use of metaphors such as "marathon", "mantra", or "mill", all of which indicate repetitive efforts without a prospective or imminent endpoint.

"I have always written [it] into the briefings for our top management [ ... ] What do you do with the old [mobile phone] devices? These questions are asked again. And I have asked again, again, and again, like a mantra. Rolled it out, again and again. And I believe you can change something with that after all. It is truly grueling, but it does work, I believe, quite well." (Sean) 


\subsubsection{Dodging}

Whenever possible, interviewees engage in green activities in order to enact and sustain their green identities, even when this requires sidestepping or dodging formal rules or existing structures. Participants reported two different forms of "dodging": Hidden green action and building green niches alongside or in the shadow of the formal organization. Both strategies allow employees to act upon their green identity, albeit by means that they themselves and also the organizational and social context might judge as beyond their competences. Scott bypassed formal structures when equipping his company's roof with photovoltaic panels financed by private investment of some coworkers. He put up a coworker cooperative after the company decided not to pursue his proposal of investing in a photovoltaic installation due to limited expected returns. The company was, however, willing to lease the rooftop for a symbolic price to Scott's co-op. In turn, Susan used her role as acting deputy during her superior's holidays to switch the power supplier for the entire company towards a supplier of renewable power-well aligned with her personal green attitude, but against the presumed economic and political interests of her employer:

"And, so there are really only very few electricity suppliers that [offer] sustainable green energy. [ ... ] And then I thought, well now, come on?! [ ... ] It will be done now. And I also won't talk about it. I'm just doing it. I can sign the contracts and no one really knows actually. I will just do it."

Non-compliance with organizational rules or structures thus allows actors to circumvent conflict and to stay true to their green identities. Megan provides an example for hidden green action by unobtrusively provoking reactions from stakeholders. Her role included working on a company report that was eventually to be published. Since, through her formal role, she was forced to take a position in the report that she personally found environmentally harmful, but her superiors were unwilling to change, she deliberately overstated the company's official case and provided details that she felt would trigger public scrutiny regarding her employer's limited ecological policies. Hidden action involves substantial job crafting as a form of identity work where actors not only add tasks to their portfolio, but challenge and/or take over competencies that have so far been held by their superiors.

Niche building provides a further form of dodging misalignment. With this strategy, green employees seek to create a shadow structure or a pocket inside or alongside the organization, which is more inclusionary regarding their green identities and initiatives. As described above, Scott created a spin-off organization - an employee-owned renewable energy co-op-at the margins of his employing company, through which like-minded colleagues were able to convert the company's roof into a photovoltaic facility. In this way, he was able to construct a new organization at the margin of his employing organization as a repository for his green identity, which, in turn, helped to sustain and accept identity misalignment in his ordinary job. Other interviewees use training and education initiatives in order to develop a group or network of colleagues inside their organization, which eventually allows them to enact their green identities at least in this greening niche.

\subsubsection{Dissolving}

With the "dissolving" strategy of identity work, actors seek to end or dispel the perceived misalignment at their workplaces. Three of our respondents actually quit their jobs (after the interview phase) in order to relocate into new organizations better suited to fit their green identity. All three interviewees left their former employers and became involved in start-ups with a focus on green products or services (e.g., e-mobility or renewable energy). These new contexts allow them to perceive their self-concept and the surrounding organizational environment as homogeneous, and thus to re-construct their identity as coherent over time. However, at least in our sample, only a few interviewees chose these paths. As demonstrated above, the larger proportion of the interviewees opted for endurance and sought to accept continuous struggling. 
When a full exit is not perceived as a viable alternative, e.g., for economic reasons, or an open struggle with the exclusionary organization is unpromising, shifting one's environmental engagement to the private domain is seen as a chance to reduce tensions at work. Lucy describes this by stating:

"Well, I mean: One is in a conflict. On the one hand, there is something to it, when you earn your living, I'd say, in a job that you don't put so much of yourself into. Yes, but then in your free time [ ... ], you can unfold your own activities, where you have a certain degree of control." (Lucy)

Another form of relocating identity work into the private domain involves reducing one's working time. It allows the employee to better separate between the work and the private domain. As a consequence, one's green identity becomes less relevant at work, and other identities, such as professional role identities or a "bread-winner" identity, become more salient, while in the private domain, identity work centers around the actor's green self-concept. For Rachel, this separation works quite well. She reduced her working hours and, in turn, increased her green engagement in the private sphere. She perceives her working and private life as two separate "worlds".

Other respondents use their spare time to build up competencies that might eventually help them to start a second, greener career. While Susan trained as an activist at Greenpeace and thinks of applying for a full job there, Nell is studying for a Master's degree in sustainability management parallel to her working full time on her marketing job, and considers applying for a sustainability position in her current company after graduation. Actors here prepare for a better alignment of their green identities with their careers in the future, and this helps them cope with the present misalignment.

\subsection{Resources Enabling Green Identity Work Strategies}

The interviewees in our sample largely resolve to endure the perceived tensions between their green identities and non-coherent work context. They find ways to tolerate tensions and to postpone their resolution into the future, to build niches where they can temporarily seek relief from exhausting identity work, or to bolster their green identities at work through satisfying private engagement. The ability to withstand returning conflicts at work, continuous personal derision, and frustration over a considerably long time requires, however, substantial resources. In our data, three enablers emerged that help actors endure incoherence concerning their green identity work (Table 3 ). They encompass cognitive and social resources, particularly (i) the interviewees' understanding of their organizations as a lever for change, (ii) their self-perception as "lone fighters", and (iii) the building of supportive networks with likeminded others.

Table 3. Resources for identity work.

\begin{tabular}{|c|c|c|}
\hline \multirow{3}{*}{$\begin{array}{l}\text { Resources for } \\
\text { Identity Work }\end{array}$} & $\begin{array}{c}\text { organization as } \\
\text { green lever }\end{array}$ & $\begin{array}{l}\text { "Well, I say, privately, when I place myself on the streets and hold } \\
\text { up a poster: 'Don't waste mobiles!', they would say: 'What does } \\
\text { he want from me?' But assuming I do [my initiatives at work] } \\
\text { another five years and that has some influence, [ ... ] that those } \\
\text { are billions, where you could save billions of dollars, where you } \\
\text { could basically save waste with that. And that is, with such a huge } \\
\text { corporation, an enormous lever, if it works." (Sean) }\end{array}$ \\
\hline & lone fighter & $\begin{array}{l}\text { "Who is committed, exposes oneself. And therefore takes a risk. } \\
\text { That can offer chances to find recognition as a pioneer, as an } \\
\text { expert, as an innovator-maybe to be able to actually achieve } \\
\text { something-but there are also risks. Some may consider you a } \\
\text { wise guy, an exotic, or a disturber." (Taylor) }\end{array}$ \\
\hline & $\begin{array}{l}\text { network of } \\
\text { the few }\end{array}$ & $\begin{array}{c}\text { "IIt is] mainly about hanging on and taking along those, of course, } \\
\text { who are interested or, let's say, those where you notice, they are } \\
\text { interested in supporting it, too, and that they also do something. } \\
\text { That was very important." (Scott) }\end{array}$ \\
\hline
\end{tabular}




\subsubsection{Constructing the Organization as a Lever for Change}

Regarding the interviewees' views on their relationships with their organizations, two interpretations emerged in the data. Some interviewees see themselves as "cogs in the wheel" of the organization who, due to their job position, can hardly expect to accomplish any change towards a greener workplace. Sara feels that " $[t]$ hat is the disadvantage of a major corporation, that you are a cog in the wheel that can hardly shift to the left or right. ( ... ) Oh yes, that is sometimes frustrating, that you can't just go into that direction [of environmental protection]." In this perspective, the organization is portrayed as a dominating structure that constrains or precludes the enactment of one's green identity in a satisfactory manner.

Other respondents emphasize that, although being positioned at a lower level with a limited scope of action, the organization can become a crucial "lever" for desired change on a larger societal level in the long run.

“Well [ ... ] some say then: You work for [company X]? Yes? And sustainability? Mhm!

Then I always say: Yes, sure, that's exactly where you can move something. I don't have to

be in a citizens' movement, ( . . ) I have to sit in the headquarters." (Megan)

Here, the organization is described as an enabling structure towards the employee's goal of a greener society. If the actor is able to endure and persist just long enough, change might eventually be attainable. There are a number of respondents in our sample who prefer talking about potential long-term effects of their engagement rather than about current frustration and organizational obstacles. In this way, they help themselves to keep up the "marathon" even in the face of current ineffectiveness.

\subsubsection{Perceiving Oneself as a "Lone Fighter"}

Green employees in our sample oftentimes feel isolated from their organization and their colleagues. They feel they must keep up their green engagement against an uncaring majority even if they risk social disadvantages, such as being ridiculed or being perceived as a nuisance by their colleagues. Nell describes how she consciously positions herself as different:

"And in the end, you somehow have to reflect on it, and then-some people might think: That is arrogant-but you have to have, somehow, enough self-esteem to say to yourself: 'No, the way I am is completely alright.' And you don't have to conform. And why should I conform? ( ... ) I don't accept that I have to change my personality just to seem well adjusted (... ). I just don't want to become like my colleagues." (Nell)

However, questioning the uncomfortable social situation at work seems to strengthen rather than weaken the interviewees' identity work. This is accomplished through a movement of identity reversal in which the actors proactively mark themselves as "crazy" (Rebecca, Megan), "weirdos" (Sara), "exotics" (Thomas), or "pioneers" who necessarily reside outside the realm of the "normal" mainstream.

Seeing oneself as an "exotic" provides a frame in which isolation is a natural correlate rather than a social problem. In addition, being a "pioneer" or "innovator" requires being ahead and thus outside of the mainstream, yet without the negative smack of being a social outcast. By seeing oneself as special and vanguard, actors are able to positively buffer their identity work in an unsupportive organizational context. It also helps to understand why some of the interviewees do not really strive to enlarge the circle of green activists at work. In a generally greener organizational context, they would eventually have to give up on an identity as a "lone fighter".

\subsubsection{Building Supportive Networks}

At the same time, those green employees who already have a network of green colleagues seem to be better prepared to withstand identity incoherence at work. Interviewees report that without likeminded allies, they would have given up their "marathon" long ago. 
"[ . .. ] before there was this connection to Kate and Lisa, I had been thinking intermittently: 'No, no, after the probation period, I'll be gone.' [ ... ] Because: You get crazy. When you have such a position of a lone fighter, and you don't know, somehow, 'Whom can I tell what', and there is no exchange, and you feel somehow completely lost, right?" (Megan)

Likeminded colleagues provide social resources, which vary depending on the coalition's nature. For some interviewees, it is important to be surrounded at least by some equally green colleagues so that they can share frustrations and provide mutual support for the green cause (e.g., Megan). Richard, for example, established a small community at work in which colleagues share a common interest in green consumption on the job. Others are content as long as they know they are not alone in their organization, but do not aim for frequent personal interaction. For example, Scott does not strive to ameliorate perceived tensions on a day-to-day basis, but rather draws on other green colleagues whom he hardly knows as part of a loosely coupled network for specific green projects of his. Here, other green colleagues function as a silent resource to be called in when needed rather than as a continuous source of emotional consolation.

\section{Discussion}

\subsection{Contribution}

The findings from our study contribute to the literature on identity tensions in two ways: First, we extend the research on identity work by identifying strategies employed by lower-level green employees. Second, we contribute to literature on job crafting by demonstrating how job crafting is essentially intertwined with identity work.

Regarding identity work strategies, we find that the strategies employed in our sample differ from typologies developed for top management $[14,15,41]$ and sustainability managers $[13,16]$. Green employees on lower hierarchical levels resort to identity work strategies that mirror their limited scope of action for changing the organizational context vis-à-vis top managers and sustainability managers, who do have access to corporate resources and/or formal decision-making legitimacy. The dodging strategy in particular seems to reflect the limited legroom for green initiatives that lower-level employees perceive in their formal job design: They feel themselves forced-and legitimated-to overstep formal rules and roles or to bypass formal organizational structures in order to enact their green identities. From the employees' perspective, the actions might come close to the concept of "useful illegality" [57,58], since they feel a need to transgress their competencies to better serve the "good cause" of greening the organization. In addition, the exposing strategy-similar in kind to Hirschman's famous "voice" strategy [59]—seems to be idiosyncratic to the green lower-level employees in our sample. While the actors in designated roles, such as sustainability managers, are ex officio and quasi automatically visible and recognizable as "the greens" in their organizations, green employees in other job roles have to find alternative ways of communicating their green orientation to colleagues and the work context at large. They do so by broadly exhibiting green artifacts (songs, stickers) or by performing repetitive scripts favoring pro-environmental behavior (reminding colleagues of double-sided printing, asking the same questions again and again).

In contrast with the strategies of distancing and deflection identified by Allen and colleagues [15,41], lower-level green employees embrace and accept non-alignment, particularly with the enduring strategy. Similar to the sustainability managers investigated by Carollo and Guerci [16], they use metaphors in their identity work to make sense of the perceived misalignment or sustainability paradox. We identify two major differences in the use of metaphors between the managers and lower-level employees: First, while the metaphors employed by managers imply progress and depict an image of green action as slowly but irresistibly affecting the whole organization (a "virus" that eventually "penetrates the organizational body") [16], lower-level green employees use metaphors denoting indefinite plight (a " $\operatorname{cog}$ ", a "marathon", a "mill"). Second, sustainability managers use metaphors that imply a level of agency and a valuable role for the organization: The "good parents" will eventually succeed in 
educating their less green "children" [16]. In addition, the metaphor of the "activist in a suit" indicates an insider role as a suit-wearing organizational man, and thus at least some kind of identification with the business world [16]. In contrast, green lower-level employees in our study describe themselves as "weirdos" and "lone fighters" or "outsiders", thereby marking a marginal role within the organization.

Interestingly, the green employees in our sample draw on identity work strategies that confirm and stabilize their social identities as "lone fighters" and "weirdos" rather than on those that would help in breaching their solitary positioning and in building social linkages, which eventually could boost organizational change. While dodging effectively precludes sharing and integration with others, since it needs to remain below the organizational radar, enduring and exhibiting, which involve the "mill" or "mantra"-like repetition of the same questions again and again, seem to put off others rather than draw them in regarding green issues-at least according to the narratives related by our interviewees. At the same time, actors are conscious about their needing others to eventually achieve success in their green initiatives. We propose that the identity work of green actors here turns into a vicious cycle that effectively prevents them from realizing the potential for sustainability transformation in organizations, which some authors $[1,2]$ like to ascribe to them.

Our second contribution concerns the concept of job crafting. While, so far, research on coping with identity tensions has focused on either identity work or job crafting [17], we demonstrate with our study that identity work and job crafting, from the perspective of green actors, are highly intertwined (Figure 2). We advance the theoretical conceptualization proposed by Kira and Balkin [17] by concluding that narrative identity work and job crafting need to be understood as interrelated processes of coping with identity tensions. Upholding one's identity as green in a non-supportive context involves redefining one's job, particularly when the job itself does not directly relate to those areas of sustainability that actors are most interested in, and thus precludes enacting one's identity through one's assigned tasks. This is evidenced by actors such as Susan, who, as a financial accountant, additionally involves herself in tasks such as advising on procurement (paper, detergents), travel policies, energy management, and sustainability training at her workplace. The extension of one's job toward integrating sustainability tasks thus, in turn, allows the actor to keep up her self-narration as green activist.

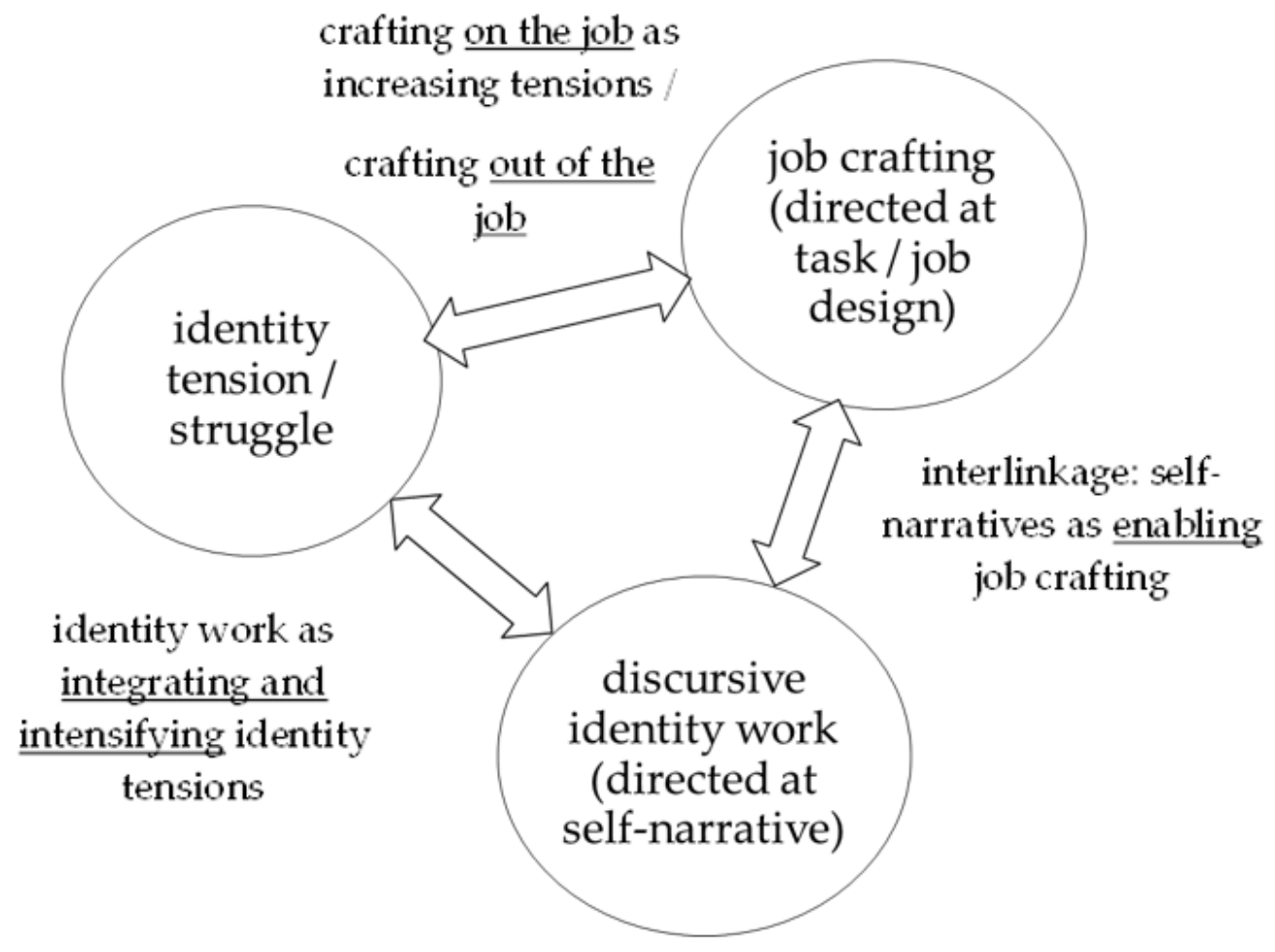

Figure 2. Paths of green identity work for lower-level employees. 
Contrary to the hypothesis advanced by Kira and Balkin [17] that lower-level employees are unable to job craft but need to resort to either enduring misalignment or changing their identity construction in response to a perceived identity tension, our study demonstrates that actors do, in fact, engage in substantial job crafting in order to maintain their green identities-despite their limited formal job discretion. While they do refrain from crafting their formally assigned jobs, e.g., as technicians, they take on additional roles and tasks pretty much unconnected to their official jobs. This means that they extend their jobs outside the boundaries of their designated jobs, which are, as hypothesized by Kira and Balkin [17], rather inflexible due to lack of autonomy and strong interdependencies. They do so by-sometimes secretly—taking on tasks of a typical sustainability professional, such as initiating green projects, training others on green issues, or readjusting corporate processes towards more sustainability. At times, this job extension is accompanied by a corresponding form of "leisure crafting" [43], when actors pursue a second course of study or professional training in sustainability-related areas in their off time. Thus, the personal engagement in our study goes well beyond a "hobby" [43], which, in the study of Berg et al., serves as an outlet for the "unanswered callings" of their interviewees.

In those cases, green identity work, job crafting, and leisure crafting activities are aligned in such a way that they do not just make the current work situation more endurable, but prepare for an "exit" [59]. Such a "crafting-out-of-the-job" strategy has been successfully pursued by three of our interviewees who, after the period under study here, moved into greener jobs and/or start-ups (sustainability consulting, renewable energy industry, e-bike shop); three more have been preparing for or were in the process of applying for dedicated sustainability jobs in and beyond their current organizations. Crafting out of the job is quite similar to the practices of responsible career building, as delineated by Tams and Marshall [60].

Contrary to other findings $[17,43]$, job crafting as a form of identity work is rather prominent in our sample. On the one hand, crafting becomes possible in lower-level jobs because actors look beyond their assigned jobs and also extend their job crafting into their leisure or spare time. On the other hand, crafting becomes possible for our sample because it is often conducted below the organizational radar, as already discussed above. It remains an issue of further research to investigate whether green employees are subject to less scrutiny or are supported by their immediate supervisors who might sympathize with their green engagement.

Our final contribution concerns the notion in the literature that identity work and job crafting are employed by green actors in organizations to cope with and/or lessen identity tensions. Regarding its effects on wellbeing, job crafting is generally seen as leading to better alignment as well as more enjoyment and meaning at work $[18,43]$. For our study, several actors instead seem to remain rather frustrated despite substantial job crafting efforts. Job crafting does not allow them to achieve alignment between their work, their green identity, and their organizational context, but rather helps them to continue enduring and thus maintaining the misalignment (Figure 2).

Building on the argumentation advanced by Kira and Balkin [17] and Meister, Jehn, and Thatcher [19], we at this point wish to draw attention to a potentially positive side of continuous misalignment: Continuous misalignment, when exhibited or otherwise communicated, might call attention to organizational blind spots and thus constitute a trigger for organizational learning. The strategies of exposing identified in our data might work in this direction, particularly if they are acknowledged rather than repressed by the organization. In addition, continuous misalignment might strengthen the actors concerned, both regarding their mindset or personality and their competencies in coping with or handling discomfort. By developing a cognitive frame that accepts misalignment, they might be better able to embrace and integrate the paradoxes and inherent contradictions associated with sustainability in organizations [61].

\subsection{Limitations and Directions for Further Research}

Although the study discloses empirical insights into the interrelatedness between job crafting and narrative identity work, on a conceptual and theoretical level, the relationship between both 
processes is much less clear. Whereas proponents from the job crafting literature have so far upheld a view positioning job crafting and identity work as two separate processes [17], researchers in the identity work tradition tend to see identity work as a broader concept encompassing narrative as well as embodied identity processes [30]. Future research needs to systematically clarify whether job crafting and narrative identity work are clearly distinguishable constructs or not. With our focus on the actual handling of identity tensions by lower-level actors and an understanding of the empirical phenomenon, this important theoretical work could not sufficiently be addressed in this paper.

There is also potential for interesting further studies on the boundary conditions of the identity work strategies of lower-level green employees. We have demonstrated on the basis of our data that the identity work strategies in use partly enforce and/or stabilize rather than moderate identity tensions and how job crafting and narrative identity work contribute to this vicious cycle. We have suggested that there are certain resources involved in enabling actors to keep up their frustrating and uncomfortable position. More research is necessary, however, in order to explore what makes actors tolerate sustained identity tensions over time. Are there certain personal characteristics and competences that help actors cope with the perceived tensions? How do organizational and institutional norms and structures interact in keeping actors in their uncomfortable positions?

This study looks at lower-level green employees situated in a highly specific social and temporal situation, which might, on the one hand, influence the identity work strategies in use in our case. On the other hand, it also clearly limits the transferability of our results to other contexts. In particular, all interviewees work in Germany, where the current labor market is rather tight. In addition, labor contracts tend to be well protected by law as well as social practice based on the German co-determination system. In this context, employees might be willing to take more risks by dodging or exiting, since they can count on attracting other, maybe more fitting employment elsewhere. At the same time, with a culture of permanent contracting and life-long careers in the same organization that is still common in the German system, employees might be expected to invest in loyalty [59], e.g., with the enduring strategy. In addition, the striving for identity coherence assumed here as an important driver of aligning one's green identity with one's job may be a (Western) cultural norm rather than a general human condition. The effects of the institutional environment on the identity work strategy are thus still undecided and merit further research.

The homogeneity of the broader cultural and institutional context might also be an explanation for the interesting finding that lower-level green employees from highly different organizational contexts (size, industry, sustainability policies) and at all ages (25 to 68 years) employ similar identity work strategies. On the basis of our data, we can only advance the proposition that the identity work strategies in use are bounded by the green identity orientation itself and the similarity of resources that actors draw from, irrespective of organizational and structural differences. A more thorough investigation of boundary conditions of identity work strategies is necessary, which should also address the question of whether identity work strategies change over time. From our study, it unfortunately remains unclear whether an exit follows a longer period of enduring (actors finally give up on the marathon) and leisure crafting (building up a second career), or whether external conditions serve as a trigger. In addition, the influence of personalities (integrator/separator disposition, cf. [62]) or personal competencies (self-efficacy, self-leadership) are beyond the boundaries of our paper, but have been shown elsewhere to impact identity work, as well as job crafting strategies [63].

\subsection{Practical Implications}

For employers, there are three risks and two opportunities arising from our study: The first risk arises from identity work strategies that interfere with an efficient performance of work tasks. If employees choose to take time for personal pro-environmental activities at work, this time is no longer available for performing their assigned tasks. If they openly resist orders from their superiors ("actively resist"), this may cause discipline problems at work and undermine their superiors' positions. If they practice "hidden green action", the employer might lose control over their behavior altogether. 
Moreover, through their active and encompassing job crafting, employees might add so many tasks to their portfolio that they increasingly feel overloaded. The second risk is brought about by the identity work strategies of "starting green" and "shift engagement". Both mean that the employer loses, fully or partly, a valuable resource and suffers a cost increase through hiring new employees. The third risk is that the employees' personal well-being might be negatively affected when they have to endure misalignment between their green identities and their job roles over a longer period of time. Apart from the fact that an employer should care about their employees' wellbeing, motivation may suffer from a reduced level of wellbeing.

On the other hand, lower-level employees with a strong green identity are also a significant opportunity: First, they are ideal candidates for green roles and positions, e.g., in CSRor environmental management departments, provided that they have the necessary fundamental skills. Second, for organizations that are heading towards more sustainability, green lower-level employees might help in triggering and shaping the green transformation from below. However, many identity work strategies identified in our study prevent the organization from learning from their green members, since green employees make use of covert activities, e.g., as part of a dodging strategy. Equipped with necessary resources and support, lower-level green employees might turn into green change agents, spearheading a bottom-up organizational transformation.

In order to mitigate the abovementioned risks and capture the opportunities, companies have to take action: The first step is to identify lower-level green employees in one's own organization. Employers can carry out an employee survey to do this, or they rely on the perceptions of their management. With the "exposing" strategies, lower-level employees already reveal themselves as green activists and may thus be easily identified by management.

As a next step, organizations might consider encouraging and supporting green employees in their job crafting efforts. Job crafting has recently been discussed as an avenue towards organizational change, albeit not in the sustainability context $[64,65]$. When in line with the overall organizational sustainability strategy, self-initiated job crafting by green employees might provide one important pathway towards redesigning roles and tasks to better align organizational work processes and structures with sustainability goals.

There are many platforms and instruments that companies can create to harness the ideas and engagement of their lower-level green employees. However, when designing these platforms, companies have to recognize the fact that acting green is a crucial identity element for these employees.

Firstly, this means that many of them want to be a part of the implementation of their green ideas. Therefore, a standard idea management system in which employees write up their ideas and then leave the evaluation and implementation to some other department will not be an adequate instrument for eliciting green employees' ideas. A platform that successfully engages green lower-level employees would have to offer them process participation and a role in implementation. This requires employers to allow these employees to use a part of their working time for working on the projects they initiated.

A second requirement is for the platforms to be open for spill-overs of green ideas from the private context, in which green employees have often gathered substantial experience with pro-environmental practices, into the work context. While this may be not so relevant for, e.g., the design of machinery or the handling of hazardous industrial waste, it may well be possible for areas such as the canteen or energy-saving practices in offices.

If the company wants the green employees to become change agents, a third requirement arises: The green employees must be visible to other members of the organization. So, the organization should facilitate networking among likeminded green employees, but also with non-green employees, and allow the green employees to turn into role models.

Using the three abovementioned requirements plus the resource implications as a touchstone will help companies design effective platforms. Thus, an idea management that gives the idea-generating employee a role in implementation and allows ideas in peripheral areas, such as the canteen, may be helpful in fulfilling the first and second requirements, but may be costly. Supporting a renewable 
energy cooperative run by employees that installs photovoltaic panels on the factory roofs, on the other hand, may incur little cost and allow employees to implement their idea, but, since the cooperative is not part of the organization, may only make limited use of green employees as change agents within the organization.

Finally, companies should reconsider the design of their career paths and work roles; by formally acknowledging sustainability-oriented job crafting, employers might open up satisfying pathways for green employees inside the organization and within or beyond the CSR/sustainability department.

Author Contributions: Conceptualization, S.B.; Supervision and Funding Acquisition, Writing-Original Draft, Writing-Review and Editing, S.B./C.H.; Formal Analysis, F.D.; Methodology and Investigation, F.D./S.B.; Writing-Original Draft, Writing-Review and Editing, A.B./A.S.B. All authors have read and agreed to the published version of the manuscript.

Funding: This work was supported by the German Federal Ministry of Education and Research (BMBF), reference number 01UN1202A. Financial support is gratefully acknowledged. The authors are solely responsible for the content of this paper and the opinions expressed.

Conflicts of Interest: The authors declare no conflict of interest. The funding organization had no role in the design of the study; in the collection, analyses, or interpretation of data; in the writing of the manuscript, or in the decision to publish the results.

\section{Appendix A}

Table A1. Interviewees' employment positions and their green initiatives at work.

\begin{tabular}{|c|c|c|c|}
\hline Name * & $\begin{array}{l}\text { Employee Position at Time of } \\
\text { Interview, Industry/Sector }\end{array}$ & $\begin{array}{l}\text { Green Activism in } \\
\text { Private/Public Sphere }\end{array}$ & Green Initiatives at Work \\
\hline Carolin & $\begin{array}{l}\text { Sales and marketing employee, } \\
\text { manufacturing industry }\end{array}$ & Ecological lifestyle & Initiated change of packaging material \\
\hline Cedric & Team leader, banking industry & $\begin{array}{l}\text { Ecological lifestyle, } \\
\text { apiculturist }\end{array}$ & $\begin{array}{l}\text { Initiated the installation of a small wind } \\
\text { turbine on the company's premises, } \\
\text { initiated sustainability reporting; } \\
\text { established a beehive on corporate premises }\end{array}$ \\
\hline Elizabeth & $\begin{array}{l}\text { Production worker, } \\
\text { manufacturing industry }\end{array}$ & Ecological lifestyle & $\begin{array}{l}\text { Resisted and revised ecologically harmful } \\
\text { practices at work }\end{array}$ \\
\hline Keith & $\begin{array}{l}\text { Business economist, power and } \\
\text { energy industry }\end{array}$ & Greenpeace activist & $\begin{array}{l}\text { Established that corporate solar parks } \\
\text { obtain the required energy from a green } \\
\text { electricity supplier; launched initiatives to } \\
\text { improve the energy consumption of the } \\
\text { transport fleet; implemented a } \\
\text { company-specific local transport pass }\end{array}$ \\
\hline Lucy & Sociologist, public sector & $\begin{array}{c}\text { Initiated solar energy } \\
\text { networks and cooperatives; } \\
\text { ecological lifestyle }\end{array}$ & $\begin{array}{l}\text { Lobbies for renewable energy and } \\
\text { energy efficiency }\end{array}$ \\
\hline Megan & Team leader, extractive industry & $\begin{array}{l}\text { Ecological lifestyle, gave up } \\
\text { her car; engages in NGOs } \\
\text { against racism/concerning } \\
\text { global migration }\end{array}$ & $\begin{array}{l}\text { Developed and promoted several green } \\
\text { ideas; engages substantially in the } \\
\text { organizational transformation towards } \\
\text { sustainability, e.g., by provoking an internal } \\
\text { discussion of corporate sustainability risks }\end{array}$ \\
\hline Nell & Team leader, extractive industry & Ecological lifestyle & $\begin{array}{l}\text { Submitted a proposal to use more electric } \\
\text { vehicles in the vehicle fleet of the company; } \\
\text { initiated a competition to promote cycling } \\
\text { to work; established an informal circle on } \\
\text { environmental issues with colleagues }\end{array}$ \\
\hline Jerry & $\begin{array}{l}\text { Product manager, chemical } \\
\text { manufacturing industry }\end{array}$ & $\begin{array}{l}\text { Climate change activist; } \\
\text { engages in ecological } \\
\text { gardening }\end{array}$ & $\begin{array}{l}\text { Engaged in discussion for renewable } \\
\text { energy in the workplace }\end{array}$ \\
\hline Patrick & $\begin{array}{l}\text { Clerk sales and distribution, } \\
\text { power and energy industry } \\
\text { [founded a green energy start-up } \\
\text { after the period of interviewing] }\end{array}$ & $\begin{array}{l}\text { Longtime anti-nuclear } \\
\text { activist }\end{array}$ & $\begin{array}{l}\text { Engaged in aligning the conventional } \\
\text { business model to the German } \\
\text { energy transition }\end{array}$ \\
\hline
\end{tabular}


Table A1. Cont.

\begin{tabular}{|c|c|c|c|}
\hline Name * & $\begin{array}{l}\text { Employee Position at Time of } \\
\text { Interview, Industry/Sector }\end{array}$ & $\begin{array}{c}\text { Green Activism in } \\
\text { Private/Public Sphere }\end{array}$ & Green Initiatives at Work \\
\hline Rachel & Geographer, geographic services & $\begin{array}{l}\text { Active in an ecological } \\
\text { association, lives in 'green' } \\
\text { co-housing project }\end{array}$ & $\begin{array}{l}\text { Lobbied for usage of trains rather than } \\
\text { flights for business travel; initiated switch } \\
\text { to fair-trade coffee; reduces her working } \\
\text { time for private green engagement }\end{array}$ \\
\hline Rebecca & Clerk, financial industry & $\begin{array}{l}\text { Active in an NGO for Africa; } \\
\text { ecological lifestyle }\end{array}$ & $\begin{array}{l}\text { Collected garbage at work to recycle at } \\
\text { home; initiated paper-less office }\end{array}$ \\
\hline Richard & $\begin{array}{l}\text { Project manager, engineering } \\
\text { industry }\end{array}$ & $\begin{array}{l}\text { Ecological lifestyle, } \\
\text { fair-trade activist }\end{array}$ & $\begin{array}{l}\text { Sold fair-trade chocolate at work and } \\
\text { donates proceeds to street children; tried to } \\
\text { achieve that official supplier switches to } \\
\text { fair-trade coffee and chocolate; openly } \\
\text { rejected a management position on } \\
\text { corporate nuclear projects; rides a bicycle } \\
\text { (with an anti-nuclear-power sticker) } \\
\text { to work }\end{array}$ \\
\hline Sandra & $\begin{array}{l}\text { Corporate development clerk, } \\
\text { insurance industry }\end{array}$ & Ecological lifestyle & $\begin{array}{l}\text { Engaged colleagues in discussion about } \\
\text { meat/veganism }\end{array}$ \\
\hline Sara & $\begin{array}{l}\text { Employee process management } \\
\text { and IT, chemical industry } \\
\text { [applied for a job in the } \\
\text { sustainability department] }\end{array}$ & $\begin{array}{l}\text { Animal protection activist; } \\
\text { engaged in pedagogical } \\
\text { projects for eco-foresting }\end{array}$ & $\begin{array}{l}\text { Requested to the CSR department to } \\
\text { compensate the } \mathrm{CO}_{2} \text { emissions of her } \\
\text { flights; launched discussions about genetic } \\
\text { engineering, animal testing, and future } \\
\text { sustainability strategies in her company; } \\
\text { applied for a job in the } \\
\text { sustainability department }\end{array}$ \\
\hline Scott & $\begin{array}{l}\text { Technical service team leader, } \\
\text { telecommunication industry } \\
\text { [left the company after the } \\
\text { period of interviewing to start } \\
\text { an e-bike shop] }\end{array}$ & $\begin{array}{l}\text { Chairman of a local lobbyist } \\
\text { group for bicyclists; helps } \\
\text { out in an eco-café and } \\
\text { e-bike shop }\end{array}$ & $\begin{array}{l}\text { Tried to established an employee } \\
\text { cooperative for renewable energy; initiative } \\
\text { for ecological modernization of the } \\
\text { company's car pool (natural gas cars, } \\
\text { electric vehicles); established photovoltaic } \\
\text { systems on the roof of company buildings } \\
\text { in shared ownership with nine colleagues }\end{array}$ \\
\hline Sean & $\begin{array}{l}\text { Clerk, transformation } \\
\text { management, } \\
\text { telecommunication industry }\end{array}$ & $\begin{array}{l}\text { Leads a sustainability group } \\
\text { in political foundation for } \\
\text { talented students }\end{array}$ & $\begin{array}{l}\text { Tried to implement a business concept to } \\
\text { reduce electronic waste and to extend the } \\
\text { durability of electronic products }\end{array}$ \\
\hline Susan & $\begin{array}{l}\text { Accountant, manufacturing } \\
\text { industry }\end{array}$ & Greenpeace activist & $\begin{array}{l}\text { Initiated the change to a green energy } \\
\text { supplier at her company without corporate } \\
\text { approval; frequently challenges } \\
\text { resource-wasteful behavior; sought to } \\
\text { establish a photovoltaic system on company } \\
\text { premises; initiated usage of recycled paper } \\
\text { and ecological detergents; compensates her } \\
\mathrm{CO}_{2} \text { emissions of each business flight } \\
\text { against corporate policy }\end{array}$ \\
\hline Taylor & $\begin{array}{l}\text { Clerk, forest management, } \\
\text { public sector }\end{array}$ & $\begin{array}{l}\text { Founded and leads several } \\
\text { cooperatives and } \\
\text { associations for renewable } \\
\text { energy }\end{array}$ & $\begin{array}{l}\text { Initiated an energy-saving program among } \\
\text { colleagues }\end{array}$ \\
\hline Thomas & Clerk, retail industry & $\begin{array}{l}\text { Leads a local } \\
\text { ecological group }\end{array}$ & $\begin{array}{l}\text { Developed and launched a game for saving } \\
\text { energy at work }\end{array}$ \\
\hline William & $\begin{array}{l}\text { Controller, automotive industry } \\
\text { [self-employed advisor on } \\
\text { renewable energy after the } \\
\text { interview period] }\end{array}$ & $\begin{array}{l}\text { Leads a national association } \\
\text { for renewable energies; has } \\
\text { founded renewable } \\
\text { energy cooperatives }\end{array}$ & $\begin{array}{l}\text { Tried to initiate the establishment of a } \\
\text { photovoltaic system on the } \\
\text { company premises }\end{array}$ \\
\hline
\end{tabular}

* Names have been changed to ensure interviewees' anonymity.

\section{References}

1. Aguilera, R.V.; Rupp, D.E.; Williams, C.A.; Ganapathi, J. Putting the s back in the corporate social responsibility: A multilevel theory of social change in organizations. Acad. Manag. Rev. 2007, 32, 836-863. [CrossRef]

2. Ciocirlan, C.E. Environmental workplace behaviors definition matters. Organ. Environ. 2016. [CrossRef] 
3. Lamm, E.; Tosti-Kharas, J.; King, C.E. Empowering employee sustainability: Perceived organizational support toward the environment. J. Bus. Ethics 2014, 128, 207-220. [CrossRef]

4. Aguinis, H.; Glavas, A. What we know and don't know about corporate social responsibility: A review and research agenda. J. Manag. 2012, 38, 932-968. [CrossRef]

5. Girschik, V.; Svystunova, L.; Lysova, E. Internal Activists as Transformers of Csr: A Typology and Research Agenda; EGOS: Tallinn, Estonia, 2018.

6. Paillé, P.; Raineri, N. Linking perceived corporate environmental policies and employees eco-initiatives: The influence of perceived organizational support and psychological contract breach. J. Bus. Res. 2015, 68, 2404-2411. [CrossRef]

7. Buhl, A.; Blazejewski, S.; Dittmer, F. The more, the merrier: Why and how employee-driven eco-innovation enhances environmental and competitive advantage. Sustainability 2016, 8, 946. [CrossRef]

8. Lo, S.H.; Peters, G.J.Y.; Kok, G. A review of determinants of and interventions for pro-environmental behaviors in organizations. J. Appl. Soc. Psychol. 2012, 42, 2933-2967. [CrossRef]

9. Lee, Y.J.; De Young, R.; Marans, R.W. Factors influencing individual recycling behavior in office settings a study of office workers in taiwan. Environ. Behav. 1995, 27, 380-403. [CrossRef]

10. Tudor, T.; Barr, S.; Gilg, A. A tale of two locational settings: Is there a link between pro-environmental behaviour at work and at home? Local Environ. 2007, 12, 409-421. [CrossRef]

11. Whitmarsh, L.; O'Neill, S. Green identity, green living? The role of pro-environmental self-identity in determining consistency across diverse pro-environmental behaviours. J. Environ. Psychol. 2010, 30, 305-314. [CrossRef]

12. Van der Werff, E.; Steg, L.; Keizer, K. The value of environmental self-identity: The relationship between biospheric values, environmental self-identity and environmental preferences, intentions and behaviour. J. Environ. Psychol. 2013, 34, 55-63. [CrossRef]

13. Wright, C.; Nyberg, D.; Grant, D. "Hippies on the third floor": Climate change, narrative identity and the micro-politics of corporate environmentalism. Organ. Stud. 2012, 33, 1451-1475. [CrossRef]

14. Cherrier, H.; Russell, S.V.; Fielding, K. Corporate environmentalism and top management identity negotiation. J. Organ. Chang. Manag. 2012, 25, 518-534. [CrossRef]

15. Allen, S.; Marshall, J.; Easterby-Smith, M. Living with contradictions: The dynamics of senior managers' identity tensions in relation to sustainability. Organ. Environ. 2015, 28, 328-348. [CrossRef]

16. Carollo, L.; Guerci, M. 'Activists in a suit': Paradoxes and metaphors in sustainability managers' identity work. J. Bus. Ethics 2017, 148, 249-268. [CrossRef]

17. Kira, M.; Balkin, D.B. Interactions between work and identities: Thriving, withering, or redefining the self? Hum. Resour. Manag. Rev. 2014, 24, 131-143. [CrossRef]

18. Wrzesniewski, A.; LoBuglio, N.; Dutton, J.E.; Berg, J.M. Job crafting and cultivating positive meaning and identity in work. In Advances in Positive Organizational Psychology; Emerald Group Publishing Limited: Bingley, UK, 2013; pp. 281-302.

19. Meister, A.; Jehn, K.A.; Thatcher, S.M. Feeling misidentified: The consequences of internal identity asymmetries for individuals at work. Acad. Manag. Rev. 2014, 39, 488-512. [CrossRef]

20. Rothbard, N.P.; Ramarajan, L. Checking your identities at the door? Positive relationships between nonwork and work identities. In Exploring Positive Identities and Organizations. Building a Theoretical and Research Foundation; Roberts, L.M., Dutton, J.E., Eds.; Routledge: New York, NY, USA, 2009; pp. 125-148.

21. Rosso, B.D.; Dekas, K.H.; Wrzesniewski, A. On the meaning of work: A theoretical integration and review. Res. Organ. Behav. 2010, 30, 91-127. [CrossRef]

22. Arvaja, M. Tensions and striving for coherence in an academic's professional identity work. Teach. High. Educ. 2018, 23, 291-306. [CrossRef]

23. Sveningsson, S.; Alvesson, M. Managing managerial identities: Organizational fragmentation, discourse and identity struggle. Hum. Relat. 2003, 56, 1163-1193. [CrossRef]

24. Brown, A.D. Identities and identity work in organizations. Int. J. Manag. Rev. 2015, 17, 20-40. [CrossRef]

25. Ibarra, H.; Barbulescu, R. Identity as narrative: Prevalence, effectiveness, and consequences of narrative identity work in macro work role transitions. Acad. Manag. Rev. 2010, 35, 135-154.

26. Clarke, C.A.; Brown, A.D.; Hailey, V.H. Working identities? Antagonistic discursive resources and managerial identity. Hum. Relat. 2009, 62, 323-352. [CrossRef] 
27. Watson, T.J. Managing identity: Identity work, personal predicaments and structural circumstances. Organization 2008, 15, 121-143. [CrossRef]

28. Watson, T.J. Narrative, life story and manager identity: A case study in autobiographical identity work. Hum. Relat. 2009, 62, 425-452. [CrossRef]

29. Alvesson, M. Self-doubters, strugglers, storytellers, surfers and others: Images of self-identities in organization studies. Hum. Relat. 2010, 63, 193-217. [CrossRef]

30. Wieland, S.M. Ideal selves as resources for the situated practice of identity. Manag. Commun. Q. 2010, 24, 503-528. [CrossRef]

31. Beech, N.; MacIntosh, R.; McInnes, P. Identity work: Processes and dynamics of identity formations. Int. J. Public Adm. 2008, 31, 957-970. [CrossRef]

32. Carlile, P.R. Artifacts and Knowledge Negotiation across Domains; Rafaeli, A., Pratt, M.G., Eds.; Lawrence Erlbaum Associates Publishers: Mahwah, NJ, USA, 2006; pp. 101-117.

33. Langley, A.; Golden-Biddle, K.; Reay, T.; Denis, J.L.; Hébert, Y.; Lamothe, L.; Gervais, J. Identity struggles in merging organizations: Renegotiating the sameness-difference dialectic. J. Appl. Behav. Sci. 2012, 48, 135-167. [CrossRef]

34. Pratt, M.G.; Rockmann, K.W.; Kaufmann, J.B. Constructing professional identity: The role of work and identity learning cycles in the customization of identity among medical residents. Acad. Manag. J. 2006, 49, 235-262. [CrossRef]

35. Baumann, Z.; Vecchi, B. Identity; Polity Press: Cambridge, UK, 2004.

36. Giddens, A. Modernity and Self-Identity: Self and Society in the Late Modern Age; Stanford university press: Palo Alto, CA, USA, 1991.

37. Pratt, M.G.; Corley, K.G. Managing multiple organizational identities: On identity ambiguity, identity conflict, and members' reactions. In Identity and the Modern Organization; Bartel, C.A., Blader, S., Wrzesniewski, A., Eds.; Lawrence Erlbaum: Mahwah, NJ, USA, 2007; pp. 99-118.

38. Ellis, N.; Ybema, S. Marketing identities: Shifting circles of identification in inter-organizational relationships. Organ. Stud. 2010, 31, 279-305. [CrossRef]

39. Nyberg, D.; Sveningsson, S. Paradoxes of authentic leadership: Leader identity struggles. Leadership 2014, 10, 437-455. [CrossRef]

40. Phillips, M. On being green and being enterprising: Narrative and the ecopreneurial self. Organization 2013, 20, 794-817. [CrossRef]

41. Alvesson, M.; Robertson, M. Money matters: Teflonic identity manoeuvring in the investment banking sector. Organ. Stud. 2016, 37, 7-34. [CrossRef]

42. Wrzesniewski, A.; Dutton, J.E. Crafting a job: Revisioning employees as active crafters of their work. Acad. Manag. Rev. 2001, 26, 179-201. [CrossRef]

43. Berg, J.M.; Grant, A.M.; Johnson, V. When callings are calling: Crafting work and leisure in pursuit of unanswered occupational callings. Organ. Sci. 2010, 21, 973-994. [CrossRef]

44. Schabram, K.; Maitlis, S. Negotiating the challenges of a calling: Emotion and enacted sensemaking in animal shelter work. Acad. Manag. J. 2017, 60, 584-609. [CrossRef]

45. Tims, M.; Bakker, A.B.; Derks, D. Development and validation of the job crafting scale. J. Vocat. Behav. 2012, 80, 173-186. [CrossRef]

46. Dutton, J.E.; Roberts, L.M.; Bednar, J. Pathways for positive identity construction at work: Four types of positive identity and the building of social resources. Acad. Manag. Rev. 2010, 35, 265-293.

47. Kornberger, M.; Brown, A.D. Ethics' as a discursive resource for identity work. Hum. Relat. 2007, 60, 497-518. [CrossRef]

48. Lincoln, Y.S.; Guba, E.G. Naturalistic Inquiry; Sage: Newbury Park, CA, USA, 1985.

49. Blatt, E.N. Exploring environmental identity and behavioral change in an environmental science course. Cult. Stud. Sci. Educ. 2013, 8, 467-488. [CrossRef]

50. Gotsi, M.; Andriopoulos, C.; Lewis, M.W.; Ingram, A.E. Managing creatives: Paradoxical approaches to identity regulation. Hum. Relat. 2010, 63, 781-805. [CrossRef]

51. Alvesson, M.; Lee Ashcraft, K.; Thomas, R. Identity matters: Reflections on the construction of identity scholarship in organization studies. Organization 2008, 15, 5-28. [CrossRef]

52. Lucius-Hoene, G.; Deppermann, A. Rekonstruktion Narrativer Identität. Ein Arbeitsbuch zur Analyse Narrativer Interviews; Leske+Budrich: Opladen, Germany, 2002. 
53. Gioia, D.A.; Corley, K.G.; Hamilton, A.L. Seeking qualitative rigor in inductive research: Notes on the gioia methodology. Organ. Res. Methods 2013, 16, 15-31. [CrossRef]

54. Niessen, C.; Weseler, D.; Kostova, P. When and why do individuals craft their jobs? The role of individual motivation and work characteristics for job crafting. Hum. Relat. 2016, 69, 1287-1313. [CrossRef]

55. Sturges, J. Crafting a balance between work and home. Hum. Relat. 2012, 65, 1539-1559. [CrossRef]

56. Kruse, J. Qualitative Interviewforschung, 2nd ed.; Beltz: Weinheim, Germany, 2015.

57. Fuller, A.; Unwin, L. Job crafting and identity in low-grade work: How hospital porters redefine the value of their work and expertise. Vocat. Learn. 2017, 10, 307-324. [CrossRef]

58. Luhmann, N. Funktionen und Folgen Formaler Organisation; HeinOnline: Buffalo, NY, USA, 1964; Volume 20.

59. Hirschman, A.O. Exit, Voice, and Loyalty: Responses to Decline in Firms, Organizations, and States; Harvard University Press: Cambridge, MA, USA, 1970; Volume 25.

60. Tams, S.; Marshall, J. Responsible careers: Systemic reflexivity in shifting landscapes. Hum. Relat. 2011, 64, 109-131. [CrossRef]

61. Hahn, T.; Pinkse, J.; Preuss, L.; Figge, F. Tensions in corporate sustainability: Towards an integrative framework. J. Bus. Ethics 2014, 127, 297-316. [CrossRef]

62. Ramarajan, L.; Reid, E. Shattering the myth of separate worlds: Negotiating nonwork identities at work. Acad. Manag. Rev. 2013, 38,621-644. [CrossRef]

63. Bipp, T.; Demerouti, E. Which employees craft their jobs and how? Basic dimensions of personality and employees' job crafting behaviour. J. Occup. Organ. Psychol. 2015, 88, 631-655. [CrossRef]

64. Petrou, P.; Demerouti, E.; Schaufeli, W.B. Crafting the change: The role of employee job crafting behaviors for successful organizational change. J. Manag. 2018, 44, 1766-1792. [CrossRef]

65. Le Blanc, P.M.; Demerouti, E.; Bakker, A.B. Better? Job Crafting for Sustainable Employees and Organizations. Intr. Work Organ. Psych. Inter. Perspect. 2017, 48-63.

(C) 2020 by the authors. Licensee MDPI, Basel, Switzerland. This article is an open access article distributed under the terms and conditions of the Creative Commons Attribution (CC BY) license (http://creativecommons.org/licenses/by/4.0/). 